\title{
Cruentaren, a New Antifungal Salicylate-Type Macrolide from Byssovorax cruenta (Myxobacteria) with Inhibitory Effect on Mitochondrial ATPase Activity
}

\author{
Fermentation and Biological Properties ${ }^{\dagger}$ \\ Brigitte Kunze, Heinrich Steinmetz, Gerhard Höfle, Markus Huss, Helmut Wieczorek, \\ Hans Reichenbach
}

Received: June 30, 2006 / Accepted: October 12, 2006

(C) Japan Antibiotics Research Association

\begin{abstract}
The novel macrolide cruentaren A was produced at levels up to $3.2 \mathrm{mg} /$ liter by cultures of the myxobacterium Byssovorax cruenta. The new compound strongly inhibited the growth of yeasts and filamentous fungi and showed high cytotoxicity against L929 mouse fibroblast cells. A minor co-metabolite of cruentaren A, named cruentaren $\mathrm{B}$, and identified as a six-membered lactone isomer of cruentaren $\mathrm{A}$, showed only marginal cytotoxicity and no antifungal activity. Cruentaren A inhibited $\mathrm{F}_{0} \mathrm{~F}_{1}$ mitochondrial ATP-hydrolysis in submitochondrial particles of yeasts and beef heart.
\end{abstract}

Keywords myxobacteria, cruentaren, benzolactone class antifungal, cytotoxic, $\mathrm{F}_{0} \mathrm{~F}_{1}$ ATPase

\section{Introduction}

Over the last 25 years myxobacteria have proved to be a consistent source of interesting and novel bioactive secondary metabolites $[1,2]$. In continuation of our screening program for new secondary metabolites, strain By c1 (=Ha r1) of the new myxobacterial genus Byssovorax cruenta [3], attracted attention because of its pronounced antifungal and high cytotoxic activity.

B. Kunze (Corresponding author), H. Steinmetz, G. Höfle, H. Reichenbach: Helmholtz Centre for Infection Research, Inhoffenstrasse 7, D-38124 Braunschweig, Germany,

E-mail: brigitte.kunze@helmholtz-hzi.de

M. Huss, H. Wieczorek: Department of Biology/Chemistry, University of Osnabrück, D-49069 Osnabrück, Germany
Bioassay-guided fractionation of culture extracts by analytical RP-HPLC showed that the antifungal and cytotoxic activity was due to one and the same major metabolite, which was isolated and structurally characterized as a 12 -membered lactone ring with a $\mathrm{N}$-acylallylamine side chain. The new compound, named cruentaren A, was accompanied by a small amount of the much less active cruentaren $\mathrm{B}$, which was identified as six-membered lactone isomer of cruentaren A. Fig. 1 shows the structures of the cruentarens, the elucidation of which is reported elsewhere $[4,5]$. Chemically, cruentarens A and B, share a common core structure with the growing class of benzolactones, including the salicylihalamides from the marine sponge Haliclona sp. [6] and the lobatamides isolated from the tunicate Aplidium lobatum [7]. Closest structural similarity exists to the V-ATPase inhibitor apicularen A, produced by several species of the myxobacterial genus Chondromyces [8 10]. Here we mainly report on the production, and some of the biological properties of cruentarens A and B.

\section{Materials and Methods}

\section{Producing Organism and Culture Conditions}

Byssovorax cruenta gen. sp. nov., nom. rev., strain By c1

${ }^{\dagger}$ Article No. 104 on antibiotics from gliding bacteria. Article No.103: Niggemann J, Bedorf N, Flörke U, Steinmetz H, Gerth K, Reichenbach H, Höfle G. Eur J Org Chem 2005: 5015-5018 (2005) 
<smiles>CCCC(O)C(C)C(=O)NC/C=C\CC(C)C(O)C(C)C1C/C=C\CC(C)C(O)Cc2cc(OC)cc(O)c2C(=O)O1</smiles>

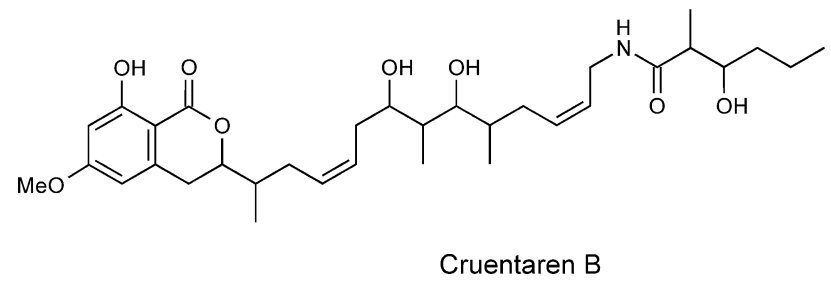

Fig. 1 The structures of cruentarens $A$ and $B$.

(formerly Byssophaga cruenta, Ha r1) was isolated at the GBF in 1997 from a soil sample collected in a sagebrush steppe near Holbrook, Arizona, USA. The organism could be obtained by the standard methods described by Reichenbach and Dworkin [11]. It grew well on living Escherichia coli, lyzing the food bacterium. Preferentially, the strain was cultivated on $\mathrm{VY} / 2$ agar composed of baker yeast $0.5 \%, \mathrm{CaCl}_{2} \cdot 2 \mathrm{H}_{2} \mathrm{O} 0.1 \%$, vitamin $\mathrm{B}_{12} 0.5 \mathrm{mg} /$ liter, agar $1.5 \%, \mathrm{pH} 7.2$. With pieces of filter paper on the agar or when maltose was added to the medium, reinforced growth was observed. In liquid culture the strain was cultivated in $\mathrm{VY} / 2$ medium with the addition of $0.2 \sim 0.5 \%$ maltose (added after sterilization) and $50 \mathrm{mM}$ HEPES, pH 7.2. Batch cultures of $100 \mathrm{ml}$ or $400 \mathrm{ml}$ in $250-\mathrm{ml}$ or $1,000-\mathrm{ml}$ Erlenmeyer flasks, respectively, were incubated at $30^{\circ} \mathrm{C}$ on a gyratory shaker at $160 \mathrm{rpm}$ for $4 \sim 7$ days. Strain By c1 grew in small red clumps. Stock cultures were preserved at $-80^{\circ} \mathrm{C}$ or in liquid nitrogen. The strain was deposited under the accession number DSM 14567 at the DMSZ, Deutsche Sammlung von Mikroorganismen und Zellkulturen $\mathrm{GmbH}$ in Braunschweig, Germany.

\section{Fermentation and Isolation}

Batch fermentations of $B$. cruenta strain By $\mathrm{cl}$ were performed in $\mathrm{VY} / 2$ liquid medium with the addition of $0.3 \%$ maltose, 10 50 mM HEPES buffer and 1.0\% (v/v) of the adsorber resin Amberlite XAD-16 (Rohm and Haas, Darmstadt, Germany). As an example, 2.0 liters of wellgrown shake cultures were inoculated into 8 liters of medium (50 mM HEPES) in a 15-liter bioreactor (Giovanola Frères, Monthey, Switzerland). The fermentation was carried out at $30^{\circ} \mathrm{C}$, with an aeration rate of 0.5 liter air per minute and an agitation at $45 \sim 55 \mathrm{rpm}$ with a flat-blade turbine stirrer. After 7 days, the content of this seed bioreactor was inoculated into a 150-liter bioreactor equipped with a flat-blade turbine stirrer (Bioengineering, Wald, Switzerland), containing 80 liters of medium (with $10 \mathrm{mM}$ HEPES) and $1.0 \%(\mathrm{v} / \mathrm{v})$ of the adsorber resin Amberlite XAD-16. The production bioreactor was kept at $30^{\circ} \mathrm{C}$, aerated with 3 liters air per minute, and agitated at $100 \mathrm{rpm}$. The $\mathrm{pH}$ value rose till the end of the fermentation after 7 days from about 7.2 to 7.4 and the $\mathrm{pO}_{2}$, recorded with a polarographic oxygen electrode decreased from $95 \%$ to $85 \%$.

At the end of the fermentation the cell mass together with the Amberlite XAD-16 adsorber resin was collected by centrifugation and extracted with acetone. Subsequently, the combined and concentrated crude extract was further purified by partition between water and ethyl acetate, followed by chromatography on silica gel Si 60 and preparative HPLC (RP18, Kronlab ODS AQ $12016 \mu \mathrm{m}$ ) as described in detail elsewhere [4].

\section{Analysis of Secondary Metabolites}

The spectrum and quantitative analysis of secondary metabolites produced by $B$. cruenta was determined in aliquots of concentrated acetone extracts by diode-arraydetected analytical HPLC using a Hewlett Packard HP1100 instrument. Chromatographic conditions were as follows: column $125 \times 2 \mathrm{~mm}, 5 \mu \mathrm{m}$, Nucleosil C18, solvent: acetonitrile/water isocratic $55: 45$, flow $0.3 \mathrm{ml} / \mathrm{minute}$, diode array detection.

\section{Biological Spectrum}

Standard strains for testing the biological activity were obtained from the DSMZ and the stock collection of our laboratory at the GBF.

The antimicrobial spectrum of cruentarens A and B was determined by an agar-plate diffusion assay using paper discs as described previously [12]. The minimal inhibition concentrations were determined with the serial two-fold dilution method. As an inoculum $1 \times 10^{6}$ cells were used. The antibiotics were dissolved in methanol, giving $\mathrm{MeOH}$ concentrations in the cultures of not more than $3 \%$. Cytotoxicity against L929 mouse cells (connective tissue, ATCC CCL 1) was assayed as reported [13].

\section{Preparations of Mitochondria, NADH-Oxidation and ATPase Assays}

Yeast mitochondria were isolated as described previously [14]. In some cases the yeast cells mixed with glass beads were only homogenized in a mini-shaker (Ika). Beef heart mitochondria were isolated by differential centrifugation as reported earlier [10]. Submitochondrial particles (SMP) 


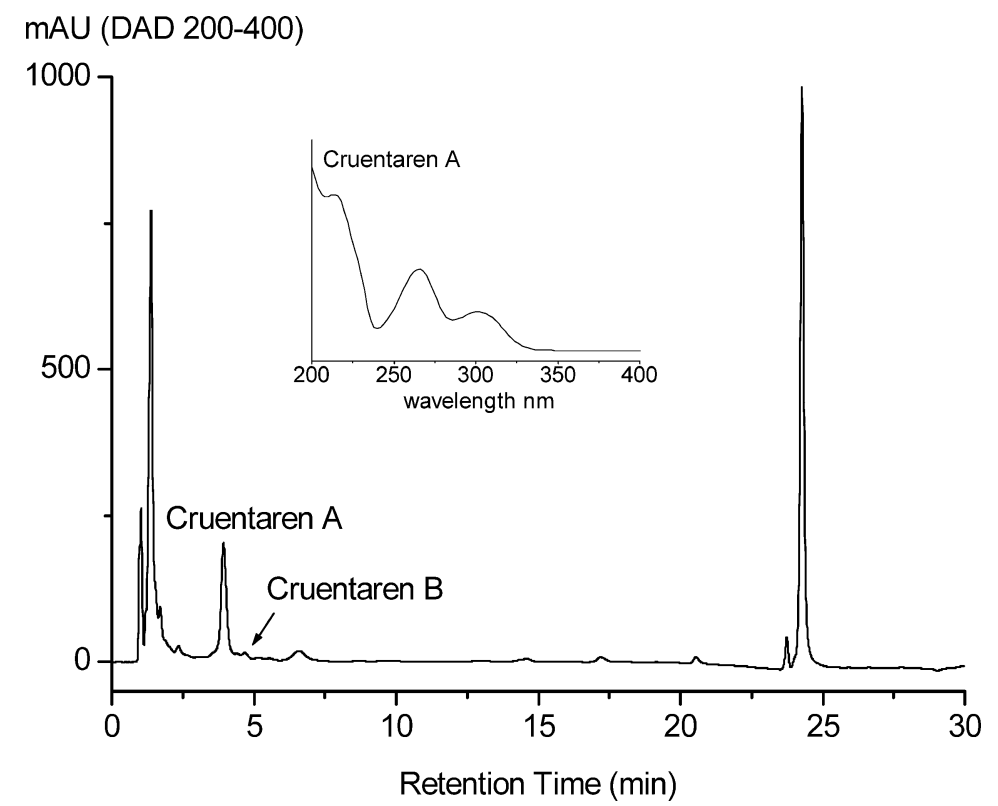

Fig. 2 HPLC profile of a crude extract from a fermentation of Byssovorax cruenta Ha r1, and overlaid the UV spectrum of cruentaren A.

were obtained by ultrasonic treatment of the mitochondria. NADH oxidation in SMP was tested in a UV2 Unicam UV/VIS spectrophotometer as described previously [15].

ATPase assays were performed in a final volume of $1000 \mu \mathrm{l}$ and at a $\mathrm{pH}$ of 8.0 with $2.7 \sim 3.4 \mu \mathrm{g}$ protein, $50 \mathrm{mM}$ Tris, $50 \mathrm{mM} \mathrm{KCl}$ and $2.5 \mathrm{mM} \mathrm{MgCl}$. After 5 minutes of preincubation with or without inhibitors, $5 \mathrm{mM}$ ATP was added, and after an additional incubation time of 15 minutes the reaction was stopped by the addition of $0.4 \mathrm{ml}$ of $20 \%$ TCA. Inorganic phospate produced in the assays was measured as blue coloured phosphomolybdate complex at $740 \mathrm{~nm}$ according to the method of Fiske and Subarrow [16] using ascorbic acid as reducing agent.

\section{Results and Discussion}

Strain By c1 (=Ha r1) shows a conspicious red pigmentation untypical for myxobacteria. The vegetative cells are typical of the suborder Sorangineae, and like Sorangium, the organism is able to degrade cellulose. Yet it also grew well on living Escherichia coli, lyzing the food bacterium, which is in contrast to Sorangium, that can neither grow on living $E$. coli, nor lyze it. The special characteristics of this strain made it necessary to assign it to a new genus of the order Myxococcales. It has been named Byssovorax cruenta [3].

After the organism had been adapted to growth in liquid media by a long series of transfers in shaken cultures, the production of cruentarens on a larger scale could be performed as described in the experimental section. In a 90-liter fermentation cruentaren A accumulated at the end of the fermentation at 7 days up to about $3.2 \mathrm{mg} / \mathrm{liter}$ as determined by HPLC. Isolation and purification yielded about $270 \mathrm{mg}$ of pure cruentaren $\mathrm{A}$ and $7 \mathrm{mg}$ of cruentaren $\mathrm{B}$, respectively. Figure 2 shows an analytical HPLC/DAD profile of a fermenter crude extract of Ha r1 after 7 days of cultivation.

\section{Biological Properties}

The determination of the antimicrobial activity showed that cruentaren A strongly inhibited the growth of several yeasts and filamentous fungi. Additionally, it was slightly inhibitory against a few Gram-positive bacteria but completely inactive against a series of Gram-negative bacteria (Table 1). The MIC for Saccharomyces cerevisiae grown in glucose free medium was $0.4 \mu \mathrm{g} / \mathrm{ml}$. Cruentaren A also proved to be highly cytotoxic. For cultivated L929 mouse fibroblasts the $\mathrm{IC}_{50}$ was $1.2 \mathrm{ng} / \mathrm{ml}$. Cruentaren B showed no antimicrobial activity up to $20 \mu \mathrm{g} / \mathrm{disc}$ and with an $\mathrm{IC}_{50}$ of $1.0 \mu \mathrm{g} / \mathrm{ml}$, it was only marginal cytotoxic for L929 cells. Because of higher activity of cruentaren A against $S$. cerevisiae when grown on glucose free medium we suspected that the new compound acted on a target associated with mitochondria. Our experiments to examine the mitochondrial electron transport chain (complex I, complex $b c_{1}$ and complex IV), showed that, up to a concentration of $8 \mu \mathrm{g} / \mathrm{ml}$, cruentaren A did not influence 
NADH oxidation in submitochondrial particles of yeasts and beef heart, respectively (data not shown). In a further attempt to uncover the mechanism of action of

Table 1 Cruentaren A: Antimicrobial spectrum

\begin{tabular}{|c|c|}
\hline Test organisms ${ }^{a}$ & $\begin{array}{c}\text { Diameter of } \\
\text { inhibition zone } \\
\text { (mm) }\end{array}$ \\
\hline Escherichia coli DSM 423 & 0 \\
\hline Salmonella typhimurium DSM 5091 & 0 \\
\hline Pseudomonas aeruginosa DSM 1117 & 0 \\
\hline Bacillus subtilis DSM 10 & 16 \\
\hline Micrococcus luteus GBF 26 & 24 \\
\hline Staphylococcus aureus GBF 16 & $\operatorname{tr}$ \\
\hline Brevibacterium ammoniagenes DSM 20306 & 0 \\
\hline Corynebacterium fascians DSM 20131 & 0 \\
\hline Candida albicans GBF 129 & (24) \\
\hline Metschnikowia pulcherrima DSM 70321 & 22 \\
\hline Saccharomyces cerevisiae ${ }^{c}$ GBF 36 & (28) \\
\hline Saccharomyces cerevisiae ${ }^{d}$ GBF 36 & 33 \\
\hline Rhodotorula glutinis & 23 \\
\hline Botrytis cinerea DSM 877 & 26 \\
\hline Mucor hiemalis DSM 2655 & 28 \\
\hline Rhizopus arrhizus DSM 905 & 25 \\
\hline
\end{tabular}

a The organisms were tested on standard complex media.

${ }^{b}$ Values represent the means of at least three independent determinations. Figures in parentheses indicate incomplete inhibition.

${ }^{\mathrm{c}}$ The organism was cultivated in a medium containing $1 \%$ glucose.

${ }^{\mathrm{d}}$ The organism was cultivated in a medium containing $2 \%$ glycerol. cruentaren A, we subsequently tested the inhibitory efficacy of cruentaren A on the F-ATPase activity in both submitochondrial particles of $S$. cerevisiae and beef heart. As shown in Fig. 3, cruentaren A indeed significantly inhibited mitochondrial ATPase hydrolysis. At concentrations of $0.1 \mu \mathrm{M}$ and $1.0 \mu \mathrm{M}$, respectively, the ATPase activity in both systems was reduced to values around $10 \sim 20 \%$. While the structural related V-ATPase inhibitor apicularen A reduced this activity only slightly, the inhibitory values of cruentaren A were in the same concentration range as those measured for the specific F-ATPase inhibitor oligomycin [17].

Altogether the cruentarens are the first novel basic structures isolated from the new myxobacterial genus Byssovorax cruenta [3]. Chemically, cruentarens A and $\mathrm{B}$ belong to a growing number of structurally related macrocyclic salicylate natural compounds, e.g., salicylihalamide A [6], lobatamide A [7] and apicularen A [8 10]. While the salicylihalamides and the lobatamides were isolated from an unidentified species of the marine sponge Haliclona sp. and from different tunicate species of the genus Aplidium, respectively, apicularen A is produced by several species of the myxobacterial genus Chondromyces, e.g., C. apiculatus or C. robustus. Thus the cruentarens represent further myxobacterial compounds which resemble natural products isolated from marine inhabitants. This raises again the question whether marine animals are really the producers of such compounds, or if they are only hosts of bacterial producers. Other examples of myxobacterial compounds that are structurally related to

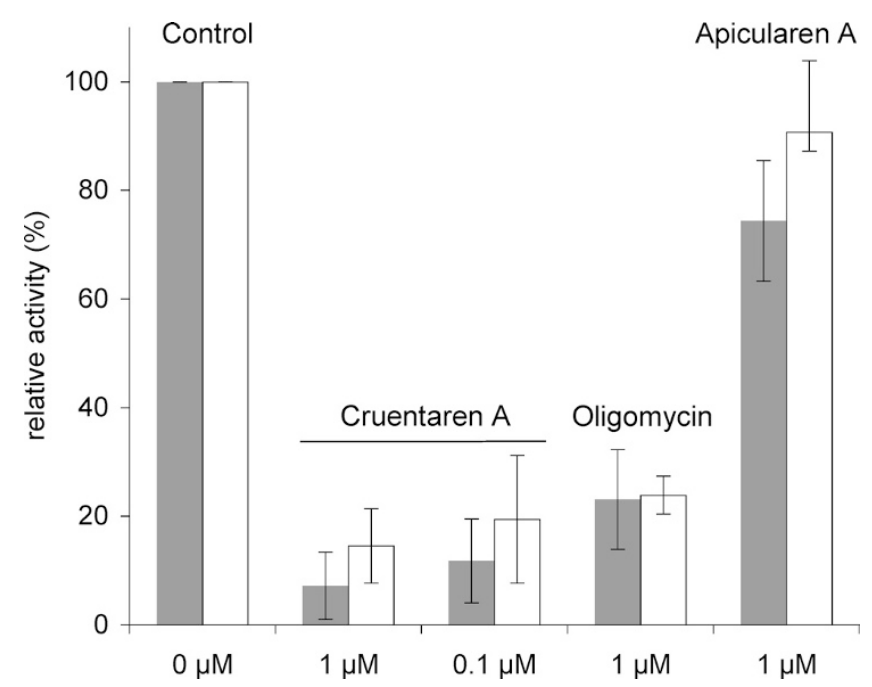

Fig. 3 Inhibition of F-ATPase activity in submitochondrial particles from Saccharomyces cerevisiae and beef heart.

Values represent the means of at least four independent experiments. The specific ATPase activity without inhibitor was $15.7 \pm 6.9 \mu \mathrm{mol} \mathrm{mg}^{-1} \mathrm{~min}^{-1}$ in S. cerevisiae (grey columns) and $7.19 \pm 2.3 \mu \mathrm{mol} \mathrm{mg}^{-1} \mathrm{~min}^{-1}$ in submitochindrial particles of beef heart (white columns). The control without inhibitor was set as $100 \%$. 
compounds isolated from sponges are the chondramides [18], which resemble jaspamide/jasplakinolide from the sponge Jaspis johnstoni [19], and saframycin [20] which is chemically related to renieramycin from the sponge Reniera sp. [21].

First investigations to unravel the mechanism of action of cruentaren A showed that it inhibited ATP hydrolysis in submitochondrial particles of both the yeast $S$. cerevisiae and beef heart and thus seems to interfere with the protonpumping mitochondrial $\mathrm{F}_{0} \mathrm{~F}_{1}$-ATPase, which is located in the inner mitochondrial membrane. This is in contrast to the structurally related apicularen A, which had no specific effect on F-type ATPases, but was shown to be a new and powerful inhibitor of the V-ATPase [10].

Acknowledgments The authors wish to thank Mrs. B. Engelhardt, S. Stock and M. Weilharter for excellent technical assistance, and the colleagues of the fermentation service of the GBF, H. Schüler, R. Krützfeldt, B. Ebert, R. Sterlinski and H. Zcazek for their contribution in large scale fermentation and downstream processing. They are also grateful to Dr. F. Sasse for performing the mammalian cell culture tests.

\section{References}

1. Reichenbach H. Myxobacteria, producers of novel bioactive substances. J Ind Microb Biotechnol 27: 149-156 (2001)

2. Reichenbach H, Höfle G. Myxobacteria as producers of secondary metabolites. In Drug Discovery from Nature ed. Grabley S, Thiericke R. pp. 149-179, Springer, Berlin, Heidelberg (1999)

3. Reichenbach H, Lang E, Schumann P, Spröer C. Byssovorax cruenta gen. nov., sp. nov., nom. rev., a cellulose-degrading myxobacterium: rediscovery of 'Myxococcus cruentus' Thaxter 1897. Int J Syst Evol Microb 56: 2357-2363 (2006)

4. Jundt L, Steinmetz H, Luger P, Weber M, Kunze B, Reichenbach $\mathrm{H}$, Höfle G. Isolation and structure elucidation of cruentaren A and B-novel members of the benzolactone class of ATPase inhibitors from the myxobacterium Byssovorax cruenta. Eur J Org Chem in press

5. Jundt L. Doctoral Thesis, Aufklärung der absoluten Konfiguration von Cruentarenen und Derivatisierung von Cruentarenen und Apicularen. Technical University of Braunschweig, (2004)

6. Erickson KL, Beutler JA, Cardellina II JH, Boyd MR. Salicylihalamides A and B, novel cytotoxic macrolides from the marine sponge Haliclona sp. J Org Chem 62: 8188-8192 (1997)

7. McKee TC, Galinis DL, Pannell LK, Cardellina II JH, Laakso J, Ireland CM, Murray L, Capon RJ, Boyd MR. The Lobatamides, novel cytotoxic macrolides from southwestern pacific tunicates. J Org Chem 63: 7805-7810 (1998)
8. Kunze B, Jansen R, Sasse F, Höfle G, Reichenbach H. Apicularen $\mathrm{A}$ and $\mathrm{B}$, new cytostatic macrolides from Chondromyces species (Myxobacteria): Production, physico-chemical and biological properties. J Antibiot 51: 1075-1080 (1998)

9. Jansen R, Kunze B, Reichenbach H, Höfle G. Apicularen A and $\mathrm{B}$, cytotoxic 10-membered lactones with a novel mechanism of action from Chondromyces species (myxobacteria): Isolation, structure elucidation, and biosynthesis. Eur J Org Chem 2000: 913-919 (2000)

10. Huss M, Sasse F, Kunze B, Jansen R, Steinmetz H, Ingenhorst G, Zeeck A, Wieczorek H. Archazolid and apicularen: Novel specific V-ATPase inhibitors. BMC Biochemistry, 2005: 6: 13

11. Reichenbach H, Dworkin M. The myxobacteria. In The Prokaryotes 2nd edn. Vol. IV, Ed., A. Balows et al., pp. 3416-3487, Springer Verlag New York, (1992)

12. Kunze B, Reichenbach H, Müller R, Höfle G. Aurafuron A and B, new bioactive polyketides from Stigmatella aurantiaca and Archangium gephyra (Myxobacteria). Fermentation, isolation, physico-chemical properties, structure and biological activity. J Antibiot 58: 244-251 (2005)

13. Mosmann T. Rapid colorimetric assay for cellular growth and survival: Application to proliferation and cytotoxic assays. J Immunol Methods 65: 55-63 (1983)

14. Thierbach G, Michaelis G. Mitochondrial and nuclear myxothiazol resistance in Saccharomyces cerevisiae. Mol Gen Genet 186: 501-506 (1986)

15. Kunze B, Jansen R, Höfle G, Reichenbach H. Crocacin, a new electron transport inhibitor from Chondromyces crocatus (Myxobacteria). Production, isolation, physicochemical and biological properties. J Antibiot 47: 881-886 (1994)

16. Fiske $\mathrm{CH}$, Subarrow Y. The colorimetric determination of phoshorus. Biol Chem 66: 375-400 (1925)

17. Linnett PE, Beechey RB. Inhibitors of the ATP synthetase system. Methods Enzymol 55: 472-518 (1979)

18. Kunze B, Jansen R, Sasse F, Höfle G, Reichenbach H. Chondramides $A \sim D$, new antifungal and cytostatic depsipeptides from Chondromyces crocatus (myxobacteria). Production, physico-chemical and biological properties. J Antibiot 48: 1262-1266 (1995)

19. Scott VR, Boehme R, Matthews TR. New class of antifungal agents: Jasplakinolide, a cyclodepsipeptide from the marine sponge, Jaspis species. Antimicrob Agents Chemother 32: 1154-1157 (1988)

20. Irschik H, Trowitzsch-Kienast W, Gerth K, Höfle G, Reichenbach H. Saframycin Mx1, a new natural saframycin isolated from a myxobacterium. J Antibiot 41: 993-998 (1988)

21. Frincke JM, Faulkner DJ. Antimicrobial metabolites of the sponge Reniera sp. J Am Chem Soc 104: 265-269 (1982) 